\title{
ENTRE LAZER, SOCIABILIDADES E INSEGURANÇA: INTERPRETAÇÕES SOBRE A PRAÇA UNIVERSITÁRIA, EM GOIÂNIA/GO
}

\author{
Matheus França ${ }^{1}$ \\ Mônica Thereza Soares Pechincha
}

\section{Apontamentos Introdutórios}

Este artigo tem como raiz uma etnografia realizada na Praça Universitária, localizada em Goiânia/GO, às sextas-feiras no período da noite, de março a outubro de 2013. Não é meu objetivo aqui, no entanto, realizar um retrato fiel de tal fenômeno, mas sim explorar a dinâmica relacional entre sociabilidades e medo convivendo mutuamente naquele contexto. Nas noites de sexta-feira, a Praça (como é comumente chamada entre os/as frequentadores/as) chega a receber cerca de 2000 a 3000 sujeitos que se classificam a partir de diversas territorialidades notadamente urbanas: hippies, punks, roqueiras/os, rappers, universitárias/os, góticas/os, entre outros - há também quem não se encaixe com nenhumas dessas redes de sujeitos. Com efeito, fica evidente que qualquer empreendimento etnográfico encontraria um campo muito vasto e denso de pesquisa. Optei, portanto, por observar as etnopaisagens que constituem processos e espaços de negociação de sentidos entre esses/as jovens, assim como explorar a relação tensa entre frequentadoras/es, que cruza sociabilidades/lazer e perigo/violência/medo. Apresentar algumas das reflexões relacionadas a esse último ponto é o meu objetivo central neste artigo.

Faço uso do neologismo de Appadurai (1996) ethnoscapes (em tradução livre, etnopaisagens), que seriam as "paisagens de identidades" de grupos que constituem determinada cena cultural. Para Appadurai, "groups are no longer familiar tighly territorialized, spatially bounded, historically unselfconscious, or culturally homogeneous"3 (Appadurai, 1996: 48). Nesse sentido, o/a antropólogo/a que se dedica a pesquisar contextos marcados por fluxos e trânsitos culturais intensos se vê obrigado/a a executar sua investigação de modo que reconheça o "cosmopolitismo etnográfico" das culturas estudadas prestando atenção aos seus incessantes devires ${ }^{4}$.

\footnotetext{
${ }^{1}$ Universidade de Brasília, Brasil

${ }^{2}$ Universidade Federal de Goiás, Brasil.

3 Tradução livre: "os grupos já não estão mais fortemente territorializados, espacialmente delimitados, historicamente inconscientes, ou culturalmente homogêneos".

${ }^{4}$ Vale a pena ressaltar que Appadurai está lidando aqui com o esquema teórico elaborado por Deleuze e Guatarri (1973) sobre territorialidades, o qual infelizmente não haverá espaço aqui para ser discutido.
} 
Desse modo, falar aqui em etnopaisagens cai bem, uma vez que se desloca a observação dos grupos em si, que estão em constante des-territorialização, para a paisagem cultural passível de ser observada a partir da constituição dessas redes. O caso da Praça talvez seja paradigmático para pensar essas questões, conforme poderá ser observado mais à frente. As etnopaisagens resultantes disso são instigantes para pensar e refletir, por exemplo, acerca dos processos pelos quais as juventudes vêm negociando identidades e subjetividades. Os limites deste artigo me impedem, no entanto, de tecer maiores considerações sobre tais processos, fazendo-me concentrar nos fenômenos mais ligados à problemática da violência - abordo mais detidamente sobre estes processos em França $(2013 ; 2014)$.

Este artigo está dividido em duas seções. Na primeira, procuro apresentar o campo e evidenciar algumas particularidades do mesmo. Na seção seguinte, exploro a questão da convivência entre medo/insegurança e as sociabilidades a partir das particularidades da Praça Universitária, onde é possível perceber que o fenômeno da violência urbana é antes um elemento constitutivo dessas sociabilidades do que um fator de dispersão das mesmas. Posteriormente, teço algumas conclusões sobre os dados apresentados, na tentativa de adensar os debates sobre essa temática (refiro-me à intersecção entre sociabilidade e violência), explorada em outros trabalhos, como por exemplo os de Zaluar (1994; 1997), Amorim (1997), Diógenes (1998), Andrade (2007).

\section{A Praça e suas sociabilidades}

Sexta-feira. Fim de tarde. Como em outros dias da semana, alguns bancos da Praça Universitária $^{5}$ estão ocupados com roda de amigas/os, casais conversando e skatistas praticando manobras por toda a extensão do espaço. O fluxo de carros, motos e ônibus cresce na medida em que o horário se aproxima das 18 horas, ficando bastante intenso a partir das 18h20: alguns/mas voltando do trabalho após uma longa semana de atividades, outros/as saindo das universidades, ou então chegando para as aulas do período noturno.

\footnotetext{
${ }^{5}$ A Praça Universitária foi idealizada ainda em 1933, na ocasião da transferência da capital goiana para a região que hoje compreende a cidade de Goiânia, fundada neste ano. Entretanto, foi inaugurada somente em 1969, com projeto urbanístico do arquiteto Atílio Corrêa Lima, na gestão do então prefeito Íris Rezende Machado. A via de acesso principal à Praça Universitária é a Rua 10, que a liga diretamente à Praça Cívica, marco inicial da capital goiana. É, também, a porta de acesso ao Setor Universitário, onde se localizam edificações e órgãos da Universidade Federal de Goiás (UFG) e da Pontifícia Universidade Católica de Goiás (PUC-Goiás), as duas maiores instituições de ensino superior do estado.
} 
É nesse momento também que a Praça, como é usualmente chamada, começa a receber seus/suas já habituais frequentadores/as noturnos/as das sextas-feiras; na medida em que cai a noite, o cheiro de maconha passa a ficar cada vez mais presente, forte. No período que compreende as $19 \mathrm{~h} 45$ e 21h30, a Praça atinge seu ápice de público, quando, além da maconha, é visível também o uso de cocaína, lança-perfume, entre outros produtos entorpecentes. Tal fato é perceptível em praticamente em todos os cantos da Praça, sendo o consumo dessas substâncias um dos elementos que mais impulsiona as sociabilidades que ali ocorrem, segundo interlocutores/as.

A Praça Universitária sempre abrigou sociabilidades - entendidas aqui enquanto um fenômeno social formado por interações entre sujeitos e as estruturas decorrentes que se estabelecem, sempre impulsionadas ou estimuladas para que certos interesses sejam $\operatorname{atingidos}^{6}$ (Simmel, 2006) - juvenis das mais diversas (desde ensaios de bateria de atléticas universitárias até shows financiados pelo governo), até mesmo porque é um espaço por onde há forte circulação de jovens, considerando, entre outros aspectos, que ela é circundada por universidades. Durante os dias da semana também ocorrem diversas sociabilidades no interior da Praça. Todavia, a frequência de pessoas nas sextas-feiras se intensificou após dois eventos em especial: o Boicote ao Chorinho ${ }^{7}$, que possuía um caráter mais relacionado à contestação de como as políticas culturais municipais vinham sendo executadas; e o A Praça é Roça, evento de rap que promovia performances ao vivo de duelos entre rappers - o foco aqui, no caso, era menos voltado para a crítica social e mais para promover sociabilidades entre os sujeitos que apreciam tal estilo musical. Uma discussão mais aprofundada sobre estes dois eventos em especial pode ser encontrada no texto integral da minha monografia (França, 2013) e em um artigo recentemente publicado sobre o protagonismo juvenil no contexto de minha pesquisa, em que problematizo especialmente o caso do Boicote ao Chorinho como um movimento de contestação política (França, 2014).

\footnotetext{
${ }^{6}$ O antropólogo Heitor Frúgoli Júnior (2007), em seu livro Sociabilidades Urbanas, realiza uma extensa revisão do conceito de sociabilidade em Simmel e do que a ideia clássica guardava de práticas estabelecidas principalmente entre "iguais”. Em consonância com a crítica de Frúguli Júnior (2007), é perceptível que as sociabilidades na Praça aqui em foco são marcadas pela heterogeneidade de gostos e estilos (Bourdieu, 1983), abrigando os mais diversos sujeitos. Inspiro-me também em Magnani (2005) em sua análise dos grupos formados por sociabilidades de jovens em centros urbanos.

${ }^{7}$ O Chorinho foi um projeto da Prefeitura de Goiânia iniciado no início dos anos 2000 que tinha como objetivo realizar apresentações musicais com canções ligadas ao samba e ao choro, ao vivo, na calçada do Grande Hotel (primeiro hotel da cidade, hoje museu e centro cultural, localizado na zona central da cidade).
} 
Porém, antes de continuar a descrição, realizarei uma breve retrospectiva de como era a Praça desde a época em que iniciei a pesquisa (por volta de março de 2013) até a época em que encerrei minha fase de campo (outubro/novembro de 2013). Se eu somente descrevesse como são as pessoas, sem demarcar que houve variação de sujeitos frequentadores da Praça ao longo dos meses, meus dados ficariam demasiadamente descontextualizados. E, mais do que isso, devo assumir que a Praça está inserida em um contexto descontínuo e transitório; ela é um lugar onde emergem sujeitos que migram, se deslocam, entram em contato com inúmeros outros, por meio de diversos mecanismos de comunicação e informação. Por isso, cabe dizer que não só a Praça mudou ao longo dos meses, mas também que ela passa constantemente por processos de ressignificação tanto dos sujeitos que a constituem, quanto do próprio pesquisador que, inserido em campo, também participa dos significados compartilhados por quem ali está.

Quando iniciei meu trabalho de campo, em março de 2013, ou mesmo nas idas à Praça de dezembro de 2012 a fevereiro de 2013 - que chamarei aqui de pré-campo -, o caráter de "crítica cultural" no âmbito das sociabilidades, especialmente daquelas mais ligadas ao Boicote ao Chorinho, já parecia ter se esvaziado. Ao mesmo tempo, os duelos de rap do A Praça é Roça (que teve seu auge no segundo semestre de 2012) estavam ficando cada vez mais escassos. Naquela época, a Praça contava com diversas bancas de venda de bebidas espalhadas por toda a sua extensão; essas bancas eram responsáveis, nos dias que não havia duelos de rap, pela musicalidade do ambiente. Em cada canto do espaço ouvia-se uma música diferente, e os estilos mais tocados eram sempre rap, hiphop, reggae e rock e, mais para o final da noite, uma das bancas tocava músicas nacionais, mais especificamente referentes ao rock dos anos 80 , ou mesmo 70 - por exemplo, as músicas do cantor baiano Raul Seixas eram indispensáveis, e toda semana marcavam presença.

Este foi um dos primeiros pontos a me chamar a atenção: por que a Praça sempre está tão cheia na sexta-feira de noite, ainda que não se tenha nenhum evento específico acontecendo? Ainda que houvesse algumas barracas de bebidas tocando músicas diversas, reunindo grupos de jovens de diferentes lugares, eu me questionava sobre como essas sociabilidades se tornaram tão fortes a ponto de reunirem milhares de pessoas no mesmo espaço sem que houvesse nenhum evento em especial. Ao lançar questões para os/as frequentadores/as sobre essa minha inquietação de pesquisa, a resposta geralmente vinha associada a uma noção de sociabilidade fortemente ligada ao lazer. Como me disse 
uma das minhas interlocutoras principais, "a galera vai pra Praça porque lá todo mundo sabe que você vai encontrar diversos amigos, pode beber, fumar [maconha], sem a polícia incomodar". Em entrevista, um de meus interlocutores resumiu muito bem o que mais ouvi em campo sobre as motivações de se ir à Praça:

\begin{abstract}
Pesquisador: Mas se você fosse me dizer o principal motivo de você ir a Praça... qual seria?

Interlocutor 1: Por que eu vou pra Praça? Não sei... acho que vou lá porque tem a galera, né? E a galera vai lá porque geralmente tá todo mundo sem dinheiro e lá é uma opção muito massa, sabe? Você vê muita gente, participa de vários ambientes, sabe? Você pode ir pro Bar da $\mathrm{Tia}^{8}$, se quiser, pode ir pra Praça ver os amigos. Os amigos sempre estão lá! Eles nunca estarão reunidos em tanta quantidade... tipo, diferentes amigos, sabe? De diversos lugares... Você nunca vai ver todos eles em um lugar só com tanta facilidade.

Pesquisador: Então eu poderia dizer que as pessoas vão pra lazer e diversão?

Interlocutor 1: De certa forma, é.

Pesquisador: Mas por que a Praça Universitária e não outros espaços? Há outros espaços em Goiânia, inclusive no centro, que são baratos, ou mesmo gratuitos, onde também vão pessoas de todas essas redes que nós conversamos. Mas todo mundo se encontra mesmo é na Praça Universitária. Por quê?

Interlocutor 1: Por que em outros lugares você não vai ter a liberdade que você tem na Praça. No Martim, no Goiânia Ouro, etc. Na Praça você tem liberdade. Você pode fumar [maconha], pode transar, pode se drogar à vontade, quem quer... e a polícia não vai te incomodar.
\end{abstract}

De fato, é notória a liberdade com que se utiliza drogas na Praça, bem como a facilidade em se adquirir tais produtos. Geralmente, policiais militares dão algumas voltas por fora da Praça, ou no máximo estacionam viaturas na porta da Biblioteca Marieta Telles Machado, que se localiza no interior da Praça Universitária. Entretanto, tal liberdade mencionada acima não pode ser encarada como algo constante, ou mesmo uma garantia, mas sim como uma circunstância passível de ser colocada em xeque constantemente e a qualquer momento.

Exemplo marcante para o meu argumento foram as batidas policiais em março de 2013 que inibiram a presença do A Praça é Roça e das bancas de bebidas que tocavam músicas. A Polícia Militar (PM) passou a posicionar viaturas na porta da Biblioteca Marieta Telles Machado. A minha primeira anotação em diário de campo sobre a presença da PM na Praça data do dia $1^{\circ}$ de março de 2013. Duas semanas depois, algumas viaturas da PM entraram na Praça e começaram a revistar diversas pessoas lá dentro. Muitos sujeitos, provavelmente porque portavam drogas ilícitas, fugiram dos oficiais,

\footnotetext{
${ }^{8}$ Um dos principais bares frequentados por universitários/as de Goiânia há mais de 20 anos, localizado no interior da Praça Universitária.
} 
provocando muito tumulto e correria entre todas as pessoas presentes no lugar. Na sextafeira posterior, a cena se repetiu.

$\mathrm{Na}$ seguinte, a Praça havia "mudado de cara" drasticamente. Não mais se via aquelas barracas que tocavam música espalhadas pela praça - no máximo, algumas pessoas vendendo bebidas em caixas de isopor, e uma ou outra banca de espetinho ${ }^{9}$. Havia menos pessoas naquela noite, assim como nas duas semanas posteriores. Chegou-se a pensar que o "movimento da Praça", como eram chamadas essas sociabilidades na época por algumas pessoas, acabaria. Tanto que houve certa polêmica no grupo do Facebook "A Praça é Roça" sobre a sugestão de uma das integrantes do grupo online de transferir o "movimento" para outra localidade da cidade: a Praça Tamandaré, que fica no Setor Oeste (bairro nobre da cidade). Entretanto, essa ideia teve poucas adesões e defesas, sendo logo descartada, uma vez que se chegou ao consenso de que, embora houvesse a possibilidade de a Polícia Militar estar doravante sempre presente na Praça, havia o entendimento de que ela não ficaria vazia por ser um espaço amplo e recentemente revitalizado pela Prefeitura, com muita área verde gramada, bem como diversos bancos, o que torna mais agradáveis as sociabilidades.

Além disso, é um local de fácil acesso para quem utiliza o transporte público da capital, uma vez que pela Praça Universitária passam diversas linhas de ônibus, além de ela se localizar próximo tanto a um dos principais terminais de integração de ônibus da cidade quanto à Praça Cívica, por onde passam linhas de ônibus com destino a todas as localidades da cidade. Ademais, fica perto da Avenida Anhanguera, na qual circulam ônibus também durante a madrugada. Acreditou-se, portanto, que "A Praça" continuaria.

E continuou. Mesmo sem atividades culturais de boicote ao Chorinho; mesmo sem duelos de rap, que deixaram de acontecer a partir de março; mesmo sem as barracas de bebidas que tocavam as músicas. Percebi que o que move a Praça, definitivamente, não é a música, embora ela não seja completamente descartada: até hoje há rodinhas de violão na parte gramada da praça entre a biblioteca e a região central, assim como caixas de som que vez ou outra aparecem em algum canto da Praça, ou mesmo a música que vem do Bar da Tia, que se pode ouvir a certa distância.

Com efeito, estas sociabilidades as quais eu me refiro se formaram principalmente a partir de grupos de pessoas que frequentavam certos espaços da cidade comumente

\footnotetext{
${ }^{9}$ Prato típico que consiste em cubos de carne espetados em um palito de madeira, geralmente servido acompanhado de arroz, mandioca e feijão tropeiro.
} 
associados à cena underground ${ }^{10}$, notadamente marcados pela presença de jovens, muitas/os delas/es punks, rockers, góticos, headbangers, entre outros sujeitos que não necessariamente se classificam unicamente a partir dessas identidades coletivas, mas que também constituíam essa cena. Para Magnani (2005), a

cena é constituída pelo conjunto de comportamentos (pautas de consumo, gostos) e pelo universo de significados (valores, regras) exibidos e cultivados por aqueles que frequentam os lugares "certos" de determinado circuito. Em resumo, pode-se "frequentar" o circuito, mas "pertence-se" a tal ou qual cena (Magnani, 2005: 202).

A cena, nesse caso, diria respeito a um universo simbólico mais ou menos restrito que conjugaria significados comuns a um grupo de sujeitos, de maneira que somente quem compartilha determinados códigos está social e culturalmente autorizada/o a pertencer a uma cena. Com efeito, na cidade de Goiânia é possível perceber a existência de uma cena underground, conforme dito acima, por meio da qual a Praça seria um dos espaços legítimos de frequência dos sujeitos que pertencem a ela.

Dessa maneira, a partir de março começa o período de sociabilidades na Praça voltadas para lazer e diversão entre jovens que não aconteciam a partir de algum evento específico, como o Boicote ao Chorinho e o A Praça é Roça, mas que ainda assim reuniam milhares de jovens todas as sextas-feiras no período da noite. O que me instigava na época enquanto problema de pesquisa era justamente o fato de sujeitos tão diversos ocuparem o espaço da Praça Universitária e constituírem etnopaisagens com uma gama de diversos estilos e acionamento de identidades.

Com relação ao conteúdo das sociabilidades, pode-se dizer que estas acontecem de maneira muito endogâmica, fechadas nas rodas de amigas/os. De modo que a Praça, nos momentos em que se encontra mais cheia, fica permeada de diversas rodinhas, seja no gramado próximo ao Bar da Tia, nos bancos que estão espalhados por toda a extensão do lugar, no gramado acima dos bancos, ou mesmo na parte mais próxima da biblioteca. À medida em que a Praça vai atingindo seu auge de público, as rodinhas vão crescendo. Nesse ponto, há certa homogeneidade entre os diversos grupos que ali frequentam: no início da tarde, é possível ver pessoas sozinhas sentadas nos bancos, ou no máximo com mais duas. Com o passar do tempo, outros sujeitos vão se agregando à roda. Esse detalhe

\footnotetext{
${ }^{10}$ Segundo Oliveira Júnior (2011), o underground "caracteriza-se por ser um espaço de convivência e produção cultural marginal e supostamente alheio à lógica capitalista, reproduzindo-se quase que exclusivamente através de meios midiáticos especializados" (Oliveira Júnior, 2011: 07).
} 
casa muito bem com a justificativa que geralmente se dá para o "porquê de se ir à Praça": ali os/as frequentadores/as encontram "toda a galera". Mesmo as pessoas que chegam sozinhas na Praça acabam encontrando diversas/os conhecidas/os e amigas/os. Percebo que os encontros ocorrem de forma bastante hermética, no sentido de que não são todas as pessoas que estão autorizadas a adentrar aquelas rodinhas. São sujeitos que constituíram forte ligação entre si em outros espaços e em diversos momentos de suas vidas.

Nesse sentido, as rodas de conversa formadas na Praça são constituídas por pessoas que estão autorizadas a ali entrar pois já se conhecem de outros espaços. Seja entre os "malas" (categoria êmica), os manos, punks e darks, há pequenas redes que se encontram na Praça para sociabilizar. É claro que não se pode generalizar: justamente por ser um espaço de sociabilidades, é comum que muitas pessoas se conheçam ali mesmo, na Praça. Segundo muitas/os de minhas interlocutoras e meus interlocutores, sempre que vão à Praça, conhecem alguém diferente. Essa é, inclusive, uma das características de sociabilidades juvenis, marcadas muitas vezes por espontaneidade e certa dose de descompromisso com regras e convenções sociais estanques (Canclini, 2009).

Parto agora para a próxima seção do trabalho, na qual aprofundo a análise da Praça, porém agora enfocando as sociabilidades convivendo com situações de violência, cenário que a partir do segundo semestre de 2013 passou a ganhar evidência, provocando tanto na queda de frequentadoras/es da/na Praça, quanto com tensões entre esses sujeitos e a Polícia Militar.

\section{Quando a sociabilidade encontra o medo, ou o contrário.}

Goiânia, 25 de outubro de 2013.

Mais um dia de campo na Praça. Cheguei por volta das $18 \mathrm{~h} 20$, vindo a pé de casa. Ao chegar nos arredores da Praça Universitária, como de costume, atravessei a rua na porta da Casa de Estudantes da UFG e desci em direção ao centro da Praça, que naquele momento estava ainda bastante tranquilo: algumas pessoas passeando com cachorros, skatistas fazendo manobras nos bancos ainda vazios, outras utilizando os aparelhos de ginástica que ficam ao norte da Praça.

[...]

Em determinado momento da noite, por volta das 21h30, com a Praça lotada, eu conversava, em um dos bancos na parte central, com uma pessoa que havia conhecido aquela noite. Era uma estudante secundarista, com 18 anos, que estava encerrando o 
terceiro ano do ensino médio. Conversamos um pouco sobre o ENEM e o vestibular da UFG, até que nosso diálogo foi interrompido porque um rapaz (que, segundo as categorias que desde o início da pesquisa vêm sendo acionados por frequentadoras/es e interlocutoras/es, faz parte do estereótipo identificado como 'mala') passou correndo do nosso lado, sendo percorrido por vários outros. O rapaz correu na direção da Faculdade de Farmácia da UFG, na parte que convencionei chamar de 'sudoeste da Praça Universitária', mas não conseguiu escapar: um deles conseguiu alcançá-lo e, segundos depois, estava sendo espancado por diversos outros homens. À medida que os minutos passavam, mais e mais homens chegavam para chutá-lo. Acredito que estivessem ali cerca de 25 pessoas batendo nele. Um pouco acima, outro sujeito passou a ser espancado, agora no ponto de ônibus da Faculdade de Farmácia. Muitas pessoas que estavam na Praça e testemunharam a cena acionaram a Polícia Militar e uma viatura do Serviço de Atendimento Móvel de Urgência (SAMU). Os dois carros chegaram no prazo de 5 a 10 minutos depois que a situação começou a ocorrer. Rapidamente o público e os protagonistas da cena se dispersaram. Fiquei em dúvida se eu ia até o local do acontecimento, ou se aproveitava o momento para colher depoimentos de quem sabia de maiores detalhes sobre o que motivou os atos de violência. Ao perceber que o rapaz já estava sendo encaminhado para o Pronto Socorro, optei pela segunda opção.

'Briga de torcida', foi o que uma das pessoas que constituem o comércio informal de bebidas da Praça me disse. Aparentemente, aquele era um torcedor do Goiás e pertencente à Força Jovem que foi identificado pelos integrantes da Esquadrão, torcida organizada do Vila Nova. 'O cara sabe que aqui é território da Esquadrão e vem aqui só pra provocar! Ele vai ter muita sorte se tiver sobrevivido', me disse um outro comerciante que se aproximou da conversa para entender o que havia acontecido. Antes que eu pudesse fazer mais perguntas, um rapaz que estava a poucos metros de distância de mim sacou uma arma e começou a dar tiros para cima, embora num ângulo de uns $30^{\circ}$, ou seja, pouco acima da cabeça das pessoas ali presentes. Instintivamente, corri para o sul da Praça e me escondi atrás do Bar da Tia, assim como várias outras pessoas, e fiquei ali por alguns minutos. Ao perceber que as pessoas já estavam voltando para a Praça, peguei meu celular do bolso e enviei uma mensagem para a Giórgia com o seguinte texto: 'encerrando campo hoje'.

O relato acima, extraído do meu diário de campo, traz um pouco do evidente contexto violento que passou a ser presente na Praça. Assim como grande parte das pessoas que lá estavam, voltei para o centro dela, e continuei a etnografar o local. Fiquei ainda por cerca de duas horas, nas quais o meu interesse principal foi o de coletar informações sobre atos de violência que haviam acontecido na Praça até então. 
Não foi a primeira vez que presenciei tiros em trabalho de campo; algumas outras vezes eu os havia testemunhado. O diferencial, neste dia, foi o fato de estar do lado do rapaz que começou a disparar os tiros, bem como o de ele ter atirado muito próximo das pessoas que ali estavam. Acabei não encerrando o campo aquele dia, decisão tomada após eu respirar um pouco e relativizar o fato de que, afinal de contas, aquela era uma das características da Praça e que talvez fosse interessante correr o risco ${ }^{11}$ que a situação oferecia desde que eu tomasse certos cuidados, tais como o de permanecer mais tempo na parte sul da Praça e não voltar a pé pra casa após o campo.

Por outro lado e ao mesmo tempo, ressalto que, embora reconheça a importância de se relativizar a categoria risco, eu optei por não corrê-lo em diversos momentos do meu trabalho de campo. Tal decisão envolve, especialmente, a presença dos sujeitos geralmente identificados enquanto malas em minha pesquisa. Isso porque, durante a etnografia, me deparei com a necessidade de entrar em contato com estas pessoas, uma vez que a presença delas quase sempre foi a mais marcante nas situações em que eu questionava meus/minhas interlocutores/as sobre quem e como eram os sujeitos que costumavam frequentar a Praça. Ao perceber que o "Outro" presente nos discursos de quase todos/as frequentadores/as com os quais estabeleci algum tipo de contato (conversas rápidas e informais, conversas mais profundas, ou mesmo entrevistas gravadas) eram justamente estes sujeitos, me senti instigado a investigar o ponto de vista dos mesmos acerca daquelas sociabilidades.

Nas poucas situações em que de fato me aproximei dos mesmos, senti a instabilidade a que as/os frequentadores/as da Praça se referem, que pode muito bem ser resumida em uma conversa surgida durante uma entrevista com um interlocutor e uma interlocutora:

\footnotetext{
Interlocutor 2: O mala te olha diferente. Você fica com medo! Ele usa aba reta também, mas é mais sisudo, digamos. O mala não é aquela pessoa gente boa, não, que nem os manos. Mala é mala. Seu pai mesmo pode virar e falar: ah, tinha um mala ali. Pode ser que ele use essa expressão.

Pesquisador: É, porque "mala" não é uma gíria só da Praça, ou só de Goiânia.

Interlocutor 2: Sim, é geral.

Interlocutora 3: Embora eu ache esse termo muito pejorativo.

Interlocutor 2: É, soa pejorativo.
}

\footnotetext{
${ }^{11}$ Resgato, no trabalho integral da monografia, uma interessante discussão feita por Cláudia Fonseca (2013) sobre a relativização da categoria risco e a sua importância para a realização de trabalhos etnográficos, na qual ela afirma que "risco é uma categoria acusatória negociada em um campo de forças", ou seja, o risco em contextos etnográficos é, no limite, uma categoria acionada para dizer uma verdade essencializada sobre a realidade estudada pelo/a antropólogo/a.
} 
Interlocutora 3: É, é preconceituoso, sei lá...

Interlocutor 2: É preconceituoso, sim, mas agora eu vou te falar uma coisa bem simples, que todo mundo fala: você vai ter medo dele. Você pensa: não, eu não vou ser preconceituoso/a, mas quando você vê um mala, você passa longe, com medo de ele te assaltar.

Interlocutora 3: É que eu cresci em periferia, então eu estou acostumada a ver malas todos os dias. Mas é, você tem que ficar esperto...

Interlocutor 2: Quem não está acostumado, sente medo. Eu já fiz isso. Já pensei: não serei preconceituoso, vou confiar. Aí fui assaltado por ele!

Importante se faz ressaltar que essa profusão de categorias acusatórias não surgiu em campo somente a partir de um grupo específico. Independente da vinculação que meus/minha interlocutores/as pudessem ter ou não com os grupos que ali se formavam, sempre havia a marcação discursivamente negativa da presença desses sujeitos na Praça. Seja por medo, por insegurança, por desconforto: a presença mais evidente, mais comentada e mais indesejada era a dos "malas" - desde os sujeitos que ficavam só no Bar da Tia, até quem ficava nas rodinhas de violão, ou mesmo aqueles/as mais ligadas ao hiphop, que outrora participavam do A Praça é Roça. De modo que, embora eu deva considerar que há aqui uma rígida estratificação entre "quem pode frequentar a Praça" e "quem não deveria frequentar porque torna o ambiente hostil", levando a questionar que esse discurso por si só também é extremamente hostil por negar o direito à cidade (Lefebvre, 1991 [1967]) a determinados sujeitos, é preciso reconhecer que os dados de campo apontam para um profundo desconforto - mais ou menos generalizado - causado pela presença desses sujeitos pelo risco que ela oferece, especialmente em termos de integridade física.

De fato, considerei não entrar em contato direto com esses sujeitos por motivos metodológicos, especialmente porque meu tempo de etnografia foi relativamente curto, e eu estava menos interessado em conseguir acessar todas as redes de sujeitos do que observar como aquela heterogeneidade de estilos de vida poderia ajudar a pensar sobre negociações de identidades entre jovens em contextos urbanos. Além disso, percebi, ao longo do trabalho de campo, que não teria fôlego para de fato acessar os "malas", considerando que a negociação etnográfica entre mim e estes sujeitos levaria em conta situações pelas quais eu conscientemente optei por não passar: em certa medida, eu também sentia certo receio de entrar em contato mais profundo com eles. Ademais, levei em consideração que há uma pesquisa de mestrado, de cunho também etnográfico, sendo realizada no Programa de Pós-Graduação em Sociologia da UFG sobre tráfico informal de drogas (Silva, 2013), na qual um dos campos de pesquisa estava sendo também a Praça 
Universitária à época, e os interlocutores do pesquisador eram justamente sujeitos identificados enquanto "malas" na minha pesquisa.

No trecho de entrevista anterior, o entrevistado e a entrevistada em questão fazem parte de grupos de pessoas que se colocam enquanto alternativas ${ }^{12}$, no sentido de que têm um discurso contra-hegemônico, de modo que se posicionam na margem em muitas situações - o próprio fato de frequentarem a Praça já diz muito sobre isso, considerando que aquele é um espaço que afasta sujeitos de classes mais altas, bem como que têm estilos de vida considerados hegemônicos - como por exemplo, no contexto goiano, o fato de se gostar de sertanejo. De maneira que há, nos discursos desses sujeitos, dois entendimentos sobre marginalidade: o primeiro seria autodeclarado, caracterizado por aqueles/as que destoam dos padrões sociais normativamente estabelecidos, ecoando estilos de vida contra-hegemônicos, contestatórios e com certo caráter de resistência, que constituiriam então o que poderia ser chamado de "redes underground" da Praça.

O segundo entendimento de marginalidade evoca outro tipo de experiência, geralmente ligada à violência e à criminalidade, e surge quando acionadas categorias acusatórias, como é o caso dos "malas", "malinhas", "malocas" (estes são outros termos utilizados para se referir a esses sujeitos) etc. Essa discussão se remete, em grande medida, a diversas falas nativas que promovem discursivamente uma clara distinção entre o que entendem, por exemplo, entre um sujeito "mala" e um "alternativo". Nesse caso, ambos os estilos possuem elementos que podem ser encarados enquanto marginais (no sentido de que não estão no Centro em alguma medida), entretanto há uma clara diferença entre o tipo de marginalidade entre os dois: o alternativo seria um sujeito contrahegemônico e marginal na medida em que destoa de padrões de comportamento considerados hegemônicos; já o mala, além de não-hegemônico, é marginal inclusive por aparentemente oferecer risco à segurança (nesse caso, "marginal" assume um sentido muito próximo do senso comum) aos frequentadores e às frequentadoras da Praça.

No que se refere ainda à discussão sobre o medo convivendo com as sociabilidades da Praça, o trecho de entrevista a seguir sintetiza também um discurso muito presente entre as/os frequentadoras/es:

12 Com relação à categoria "alternativo", me inspiro no trabalho recente da antropóloga Giórgia Neiva $(2013 ; 2014)$ sobre a "juventude alternativa” em Goiânia/GO. 
Interlocutor 2 [22 anos, universitário]: Eu vou me sentindo desconfortável à medida em que eu vou subindo pela Praça. É estranho. Você passa por várias divisões. Quando você chega nos malas, você perde a segurança, você passa a ficar desconfiado. Você passa a conferir se está com o seu celular; você sabe que em algum momento eles vão chegar e oferecer beck. Se você for procurar, você sabe que vai achar lá, mas você vai procurar com medo. Pra se sentir seguro, é só sentar na grade do Bar da Tia.

Pesquisador: Na sua opinião, seria por isso então que quando nós vamos, nos sentamos perto do Bar da Tia?

Interlocutor 2: Isso. Você vai saber exatamente o que é insegurança quando você sair da grade do Bar da Tia e começar a subir a Praça.

Interlocutora 3 [23 anos, universitária]: Antes, eu ficava na Praça até amanhecer. Hoje em dia, quando vai dando 11 da noite eu já vou começando a me preparar pra ir embora, porque eu penso: daqui a pouco começa a rolar tiro pra cima... ficou bem mais violento lá. Mas é sério, quase todas as vezes que eu vou lá está tendo tiro!

Pesquisador: Não é desde sempre que rola essa insegurança, né?

Interlocutora 3: Não. Mas lá sempre rolou morte. Sempre rolou tiro pra cima. Só que agora, nos dias de sexta-feira, está bem pior.

Pesquisador: No começo do ano não rolava tanto. Ou eu estou errado?

Interlocutora 3: Não. Mas olha, eu não tenho medo de ficar na Praça. Eu não tenho medo de passar perto dos malas, e tal... não sinto essa insegurança, não. Mas eu sei que se eu bobear, já era. Roubam mesmo, e tal... E sempre, quando vai ficando mais tarde e a galera vai ficando mais bêbada, começam a brigar, e sempre rola tiro, quase toda sexta tá rolando tiro lá pra cima. Então quando vai dando 11 horas eu sei que vai ter tumulto, a galera vai sair correndo... mas sempre voltam! A galera continua lá ainda...

Pesquisador: E por que a galera continua mesmo sabendo que tem gente armada ali no meio?

Interlocutora 3: É porque assim, foi o seguinte... tava todo mundo lá e eu ouvi que começaram a brigar. E era perto, porque eu estava vendo. Aí começaram a rolar alguns capacetes, e de repente: pá, pá! Foi tiro pra cima. Eu estava próxima, mas quando começaram a brigar eu já fui saindo pro Bar da Tia.

Pesquisador: Em que lugar da Praça foi isso?

Interlocutor 2: Foi ali no meio, onde os malas ficam. Aí eles começaram a brigar, e quando eu vi que eles estavam brigando, eu já fui descendo e sentei lá no Bar da Tia. Porque é o lugar mais de boa! Sentei no Bar da Tia. Daí, “pá!”, e saiu todo mundo correndo. Rolou uns tiros e todo mundo saiu correndo. Aí, geralmente, quem arruma confusão vai embora. Aí, como deviam ter ido embora, e não deu em nada, e a galera queria continuar bebendo, então ficou todo mundo lá.

Pesquisador: Como funciona essa história de que "quem arranja confusão vai embora"?

Interlocutora 3: Lógico! Arrumou confusão, vai embora! Uai... não vai ficar no mesmo lugar, né? Sei lá... alguém denuncia, a polícia vai lá...

Pesquisador: Aí você corre pro Bar da Tia, então.

Interlocutora 3: É, quando eu vejo que tá tenso e eu não estou com vontade de ir embora, eu vou pra lá, porque é mais tranquilo...

Após este longo trecho de um diálogo que se estabeleceu no meio da entrevista, alguns pontos podem ser colocados em análise. Em primeiro lugar, mais uma vez é salientado que a Praça é bem dividida, e que à medida que se sobe, mais se aproxima dos malas; e que, na medida em que se aproxima dos mesmos, mais se sente medo. Esse discurso não é localizado: durante toda a etnografia tive a oportunidade de conversar esporadicamente com diversos sujeitos, e todos tinham uma opinião mais ou menos 
parecida. Em algum momento do trabalho de campo, fui convidado para "fazer o corre"13 na região dos malas. Aceitei o convite e fui com uma interlocutora naquela região. Geralmente, se pergunta "você tem aí pra passar?" para as pessoas, até que alguém tenha maconha disponível "para passar". $\mathrm{Na}$ ocasião, chegamos na região onde há maior presença dos malas; minha interlocutora e eu ficamos algum tempo ali, aguardando, até que me disse: "fala com aquele ali, ele deve ter [maconha]". Perguntei: "por que você acha que ele tem?". E ela: "porque esses malas sempre têm, e ele parece ser mais de boa". Ela se referia a um rapaz que não estava olhando tão profundamente as outras pessoas. Foi quando eu disse: "mas eu pensei que você ia me mostrar como que faz o corre". Ela: "acho mais seguro se você for". Considerando que seria melhor tomar alguma atitude e sair do espaço logo, afinal eu já estava percebendo olhares inibidores por parte de outros malas, resolvi acatar o pedido. Cheguei no mala e perguntei se "ele teria pra passar". Ele me perguntou quanto eu queria, e eu disse que seria a quantidade equivalente a $\mathrm{R} \$ 10,00$. Ele colocou a mão no bolso, pegou um pedaço de maconha e me entregou. Como eu não sabia distinguir se era muita ou pouca a quantidade que ele estava me dando - depois me contaram que aquela quantidade valia bem mais que o valor pago -, entreguei a nota de $\mathrm{R} \$ 10,00$ e saí, inclusive porque ele rapidamente me olhou com uma cara como quem diz “ok, agora sai daqui!".

Lembro-me o quanto fiquei tenso com a situação, embora hoje eu reconheça que a experiência tenha sido interessante para entender que o momento da sociabilidade pode rapidamente passar para um estágio de tensão, seja por ter de fazer o corre, por ter de passar pelos malas para atravessar a Praça, ou mesmo, em um caso extremo, porque começou a acontecer alguma briga ali por perto. Embora seja plausível talvez pensar esse estágio de tensão como uma característica inerente a essas sociabilidades, afinal o "estar na Praça", ou mesmo o "fazer o corre" implica, em alguma medida, em estar em contato muito próximo a essa sensação de insegurança.

Em segundo lugar, é interessante ver que, embora a interlocutora 3 afirme quase sempre que não tem medo dos malas, que está acostumada a vê-los porque veio da periferia (conforme dito em outro trecho de entrevista já apresentado), ainda assim ela reconhece a importância de se tomar cuidado com os malas, e que também não arrisca ficar até muito tarde na Praça, pois sabe que pode acontecer tiroteio, roubo, etc. O medo,

13 Trata-se de uma categoria êmica que significa o ato de procurar/buscar por algum tipo de substância, notadamente maconha. 
por ser uma categoria que passa pela questão da subjetividade, não pode ser mensurado, entretanto é evidente que ele está presente nos sentimentos de quem frequenta a Praça, em menor ou maior grau, e de formas distintas.

Por último, o trecho acima expõe uma característica que sempre me chamou muito a atenção: a relação que as sociabilidades/lazer estabelecem com a questão da violência - que envolve também o medo, ou a sensação de insegurança. "Ter medo" parece fazer realmente parte da constituição dessas sociabilidades.

Contudo, para grande parte das pessoas com quem conversei em trabalho de campo, sejam entre punks, roqueiros/as, hippies ou estudantes universitárias/os que para lá iam após as aulas, a iminência de que alguma situação de violência ocorra não é anunciada enquanto um fator minimamente positivo. O que se diz é que os malas têm direito de estar ali, afinal aquele é um espaço público, de todos/as. Na mesma medida, há o discurso de que a Praça seria "bem melhor" se não fosse o contexto violento - inclusive, boa parte de meus/minhas principais interlocutores/as reduziram a frequência nas sextas-feiras da Praça justamente por conta desses fatores. Por outro lado, não se deseja também que a polícia intervenha na Praça no sentido de reduzir a sensação de insegurança.

Em todas as ocasiões em que presenciei tiroteios e/ou outras brigas na Praça, percebi que grande parte dos sujeitos acabava voltando aos seus grupos de amigos/as após perceber que não haveria mais briga/tiros. Uma possível interpretação foi apontada por minha interlocutora, que é a de que "quem arruma confusão vai embora”. Contudo, acredito que, mais que isso, há outros elementos que operam na dinâmica de permanência desses sujeitos na Praça, afinal, se alguém esteve armado no lugar, pressupõe-se que outras pessoas também possam estar. De maneira que, ainda que quem atirou tenha ido embora, o problema da violência não foi resolvido: a qualquer momento alguém pode sacar uma arma novamente.

Para o sociólogo Luiz Antônio Machado da Silva (2004), que propõe como categoria de análise o conceito de sociabilidade violenta, no contexto da violência urbana "as ameaças percebidas à integridade física e patrimonial não provêm simplesmente de agentes e comportamentos isolados, mas de um complexo orgânico de práticas" (Machado da Silva, 2004: 73). Ou seja, seria preciso pensar muito mais além do que casos isolados de brigas e/ou sujeitos que vez ou outra começam uma briga na Praça. Ainda para Machado da Silva (2004), as populações que convivem com tais "sociabilidades violentas" acabam sendo submetidas às mesmas porque ela passa a existir enquanto 
ordem instituída. Ainda que ele esteja se referindo mais especificamente a contextos como o das favelas cariocas, onde há certa "lei do silêncio" no que se refere às sociabilidades violentas, acredito que seja válido pensá-las também no caso da Praça: se sabe que naquele lugar há consumo, compra e venda de drogas, e que muitos sujeitos estão ali mais por causa deste comércio do que por conta das sociabilidades enquanto forma de lazer. $\mathrm{E}$ se sabe, ademais, que alguns desses andam armados, e que vez ou outra acabam utilizando as armas como forma de defesa e/ou demarcação de território. Ainda assim, se continua frequentando o ambiente e constituindo as sociabilidades - com um forte sentimento de insegurança, mas continuam ali.

Para finalizar, cito aqui a dissertação de Najla Frattari (2009), que realiza um excelente estudo sobre o sentimento de insegurança ligado à violência urbana na cidade de Goiânia. Em diversos momentos do texto, a autora explicita que, com o aumento da sensação de medo e insegurança, a frequência a espaços públicos tem diminuído. Diz ela que

vivenciar espaços como praças, jardins públicos, ou mesmo residir em casas ou prédios de apartamentos desprovidos de aparatos de segurança parece algo cada vez menos atraente e desejável. No atual contexto de medo e ansiedade, os espaços públicos comuns têm sido abandonados em favor de espaços privatizados e protegidos com acesso controlado e restrito, sejam espaços de moradia, lazer, compras e serviços (Frattari, 2009: 96).

Nesse sentido, percebe-se que a Praça mostra uma realidade diferente: os sujeitos que ali frequentam não têm interesse em deixar de frequentar este espaço público em favor de espaços privatizados - não estou dizendo que eles/as não o frequentem, mas sim que a Praça é um espaço muito frequentado por essas pessoas.

Por fim, o sentimento de insegurança existe. Os/as frequentadores/as têm consciência e sabem que a Praça é um lugar perigoso, ou pelo menos que se deve tomar cuidado ao se frequentar aquele espaço. Entretanto, não é por isso que deixarão de frequentá-la. As sociabilidades que aqui chamei de perigosas, ao que o campo me mostrou, continuarão existindo.

\section{Considerações Finais}

Este artigo manteve a narrativa da monografia a qual inspirou a escrita desse trabalho. Entretanto, devo rapidamente mencionar que o contexto atual da Praça mudou 
bastante desde a conclusão da etnografia (em meados de novembro de 2013). No caso, ações policiais foram levadas a cabo na Praça Universitária de maneira a reduzir o "índice de violência" causado especialmente por brigas de torcidas organizadas protagonizadas pelos "malas". Hoje, portanto, a Praça voltou a receber nas noites de sexta-feira uma quantidade significativamente menor de sujeitos do que então ocorria durante minha pesquisa - na verdade, a frequência de pessoas está sendo quantitativamente semelhante aos outros dias da semana -, porém agora com a presença maciça de viaturas da Polícia Militar.

Tal fato leva a questionar: afinal, o sentimento de insegurança causado pela Polícia Militar é maior do que aquele causado pelos malas, considerando que as sociabilidades aconteciam (de certa forma) tranquilamente mesmo com tiroteios, brigas de torcidas e a presença dos malas? Por que então, com a chegada da PM, houve uma dispersão significativa de frequentadores/as?

Certamente, o medo de "levar baculejo" foi um dos principais motivadores da dispersão daquelas sociabilidades, afinal quase todos/as ali usavam algum tipo de droga. Entretanto, arrisco aqui uma outra interpretação: fica notória a desconfiança depositada em instituições legitimadas pelo Estado que a princípio teriam como objetivo principal "resguardar" a população. No caso da Praça, a presença da polícia é, muitas vezes, tão indesejada quanto a dos "malas” (responsáveis pela sensação de insegurança) - para não mencionar os diversos momentos em que ouvi que é melhor a presença dos malas do que da polícia naquele lugar. Este entendimento ficou ainda mais acentuado após a onda de protestos durante o ano de 2013, nos quais a PM protagonizou episódios de exacerbado autoritarismo, truculência e violação de diversos direitos.

Um dos pontos centrais desse artigo foi contar um pouco sobre relações de poder, eclosão de conflitos e negociações entre jovens na cidade de Goiânia/GO. Ressalta-se a característica marcante das sociabilidades da Praça de constituírem etnopaisagens descontínuas, ou seja, em constante mudança e marcadas por desterritorializações de sujeitos que ora estão ali presentes em tons de contestação política, ora indo "simplesmente para se divertirem", ora para comercializar drogas - para, algum tempo depois, deixarem de frequentá-la para estabelecerem territorialidades em outros espaços urbanos da cidade - e, quem sabe, futuramente voltar a ocupar a Praça de maneiras ainda distintas e inovadoras, impulsionadas por agenciamentos outros. 


\section{Referências}

AMORIM, Lara Santos. Cenas de uma Revolta Urbana: movimento hip hop na periferia de Brasília. Dissertação de Mestrado. Departamento de Antropologia, Brasília, UnB, 1997.

ANDRADE, Carla Coelho de. Entre gangues e galeras: juventude, violência e sociabilidade na periferia do Distrito Federal. Tese de Doutorado. Programa de Pós-Graduação em Antropologia Social. Departamento de Antropologia. Universidade de Brasília, 2007.

APPADURAI, Arjun. 1996. Global Ethnoscapes: Notes and Queries for a Transnational Anthropology. In: - Modernity at Large: cultural dimensions of globalization. Minneapolis: University of Minnesota Press: 48-67.

BOURDIEU, Pierre. Gostos de classe e estilos de vida. In: Questões de Sociologia. Rio de Janeiro: Marco Zero, 1983. p. 82 - 121.

CANCLINI, Néstor Garcia. Ser diferente é desconectar-se? sobre as culturas juvenis. In:

Diferentes, desiguais e desconectados: mapas da interculturalidade. Rio de Janeiro: UFRJ, 2009. Cláudia Fonseca: Desafios Éticos da Pesquisa Antropológica Contemporânea. 2013. Disponível em:

<https://www.youtube.com/watch?feature=player_embedded\&v=zGPrZ48-2dI >. Acesso em: 09 dez. 2013.

DELEUZE, G; GUATARRI, F. O Anti-Édipo. Rio de Janeiro: Imago, 1976.

DIÓGENES, Glória. Cartografias da Violência: gangues, galeras e o movimento hip hop. São Paulo: ANNABLUME, 1998.

FRANÇA, Matheus. "Vai pra Praça hoje?”: sociabilidades juvenis na Praça Universitária em Goiânia/GO. Monografia - Faculdade de Ciências Sociais - Universidade Federal de Goiás Goiânia, 2013.

. A Praça Universitária e suas sociabilidades: gritos urbanos de jovens em Goiânia/GO. Revista Geração Z, n. 3, v. 1:37-42, 2014.

FRATTARI, Najla. Insegurança: as práticas e discursos do medo na cidade de Goiânia. Dissertação (Mestrado) - Programa de Pós-Graduação em Sociologia - Departamento de Ciências Sociais - Universidade Federal de Goiás, 2009.

FRÚGOLI Jr., Heitor. Sociabilidade urbana. Rio de Janeiro: Jorge Zahar, 2007.

LEFEBVRE, Henri. O Direito à Cidade. São Paulo: Editora Moraes, 1991 [1967])

MACHADO DA SILVA, Luiz Antônio. Sociabilidade violenta: por uma interpretação da criminalidade... Revista Sociedade e Estado, v. 19, n. 1, p.53-84, jan/jun. 2004.

MAGNANI, José Guilherme Cantor. Os circuitos dos jovens urbanos. Tempo Social, vol.17, n.2, p. 173-205, 2005.

NEIVA, Giórgia. Juventude Alternativa. Revista Geração Z, v. -, p. 37-40, 2013. 
Nas Redes dos Alternativos - mercado, sexualidade e produção de diferenças na cidade de Goiânia/GO. Programa de Pós-Graduação em Antropologia Social - Faculdade de Ciências Sociais da Universidade Federal de Goiás. Goiânia, 2014.

OLIVEIRA JÚNIOR, Marcos Vinicius de. Do underground ao mainstream: uma etnografia do heavy metal em Brasília. 2011. 78 f. Monografia (Bacharelado em Ciências Sociais) Universidade de Brasília, Brasília, 2011.

SILVA, Guilherme Borges. Etnografando o varejo do tráfico de drogas na Região Metropolitana de Goiânia: dificuldades e entraves no processo da pesquisa. In: $37^{\circ}$ Encontro Anual de ANPOCS. Águas de Lindóia. Anais do $37^{\circ}$ Encontro Anual de ANPOCS, 2013.

SIMMEL, G. A Sociabilidade - exemplo de sociologia pura ou formal. In: Questões fundamentais da sociologia. Jorge Zahar Editor: Rio de Janeiro, 2006.

ZALUAR, Alba. Teleguiados e Chefes: juventude e crime. In: Condomínio do Diabo. Ride Janeiro: Revan/UFRJ, 1994.

. Gangues, galeras e quadrilhas: globalização, juventude e violência. In: VIANNA, Hermano (Org.). Galeras cariocas. Rio de Janeiro: Editora UFRJ, 1997.

Recebido em: 29/09/2014 Aprovado em: 05/11/2014 